\title{
A FOGYASZTÓI ATTITÚD AFFEKTÍV ÉS KONATÍV KOMPONENSEINEK ELEMZÉSE A PÁLINKA IMÁZSÁBAN
}

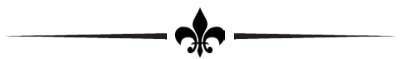

\section{ANALYSIS OF THE AFFECTIVE AND CONATIVE COMPONENTS OF CONSUMER ATTITUDE IN THE IMAGE OF THE PÁLINKA}

\author{
$-10$ \\ ${ }^{1}$ MUCHA, LÁSZLÓ \\ ${ }^{2}$ ORAVECZ, TITANILLA \\ ${ }^{2}$ TOTTH, GEDEON

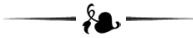 \\ ${ }^{1}$ Szent István Egyetem, Gazdálkodás és Szervezéstudományok Doktori Iskola \\ (Doctoral School of Management and Business, Szent István University) \\ H-210o Gödöllő, Páter Károly utca 1. \\ e-mail: mucha.laszlo@phd.uni-szie.hu \\ ${ }^{2}$ Budapesti Gazdasági Egyetem Külkereskedelmi Kar, Marketing Tanszék \\ (Marketing Department, Faculty of International Management and Business, Budapest Business School) \\ H-1165, Budapest, Diósy Lajos u. 22-24.
}

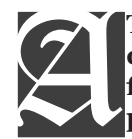

The research aim is to explore the potential role of consumer attitude components in image development related to a traditional Hungarian alcoholic beverage, the pálinka. This study focuses on the effect of the affective and conative components of attitude on image of the pálinka. The relevance of this research is the expansion of the pálinka market in recent years and the change of the regulatory environment about homemade spirits. Distillate made at home, which product improperly called homemade pálinka, is very popular in Hungary. This study was supported by the data from a nationwide, representative consumer survey carried out in 2019 and 2020. A total of 626 subjects participated in this survey, the sample is representative for the Hungarian adult population according to gender, age group and region. To understand the effect of the affective and conative attitude components, we used Likert scales and graphically illustrate the consumer feeling and behavior about the homemade spirit and the "in-store" pálinka. The study confirmed the advantage of homemade spirit image over in-store pálinka, and points out the importance of education and information in the case of the affective and conative components of consumer attitude. The reconsidering of the marketing communication of the in-store pálinka producers is timely and very important; however, this task requires a comprehensive marketing strategy covering all three attitude components, and this is the only way for them to remain competitive.

KuLCSSZAVAK: fogyasztói magatartás, imázs, attitűd komponensek, pálinka, fogyasztói etnocentrizmus

JEL-KóDOK (JEL CODES): M31

DOI: https://doi.org/10.20494/TM/8/1/2
KEYWORDS: consumer behaviour, image, attitude components, the pálinka, consumer ethnocentrism 


\section{BEVEZETÉS - INTRODUCTION}

A kutatás a kognitív, affektív, konatív attitüd komponensek imázsalakító szerepét vizsgálja egy nagy hagyománnyal rendelkező magyar termék, a pálinka esetében. A téma relevanciáját a pálinka piacának az elmúlt évekbeli bővülése, valamint az otthoni pálinkafózés és bérfózés törvényi szabályozásnak az utóbbi tevekénységek számára igen kedvező alakulása adta. A kereskedelmi pálinkák előállítói 2019re nehéz helyzetbe kerültek, melyért nemcsak a jogszabályi környezet, hanem a fogyasztói magatartás egyaránt felelős. Magyarországon az otthon, vagy bérfőzdében készített párlat, a népnyelv által pontatlanul házi pálinkának nevezett termék régóta igen nagy népszerüségnek örvend. Mindezen körülmények indokolják a fogyasztói motivációk, attitüdök alapos vizsgálatát. A fogyasztást befolyásoló tényezők azonosítása lehetővé teszi a megfelelő marketingkommunikációs stratégia kialakítását az ágazati szereplők számára, melyre jelen helyzetben nagy szükségük van. Jelen tanulmány az affektív és konatív fogyasztói attitüd komponensek pálinkaimázs alakító hatására koncentrál, a kognitív komponensre vonatkozó vizsgálatunk eredményeit egy korábbi publikációban ismertettük.

\section{SzAKIRODALMI ÁTTEKINTÉS - LITERATURE REVIEW}

TOTTH (2009), TOTTH et al. (2018a) szerint a pálinka értékes, magas minőségű magyar italként történő pozícionálásának lehetősége két évtizede adott, a pálinka a magyar nemzeti imázst hordozó italunkká válhatna, erősíti meg FODOR et al. (2011). Azonban a pálinka - világszínvonalú minősége ellenére - nem igazán ismert határainkon kívül (BALÁZS, 2012; HARCSA et al., 2014).

A korábbi pálinkafogyasztással kapcsolatos vizsgálatok (HLÉDIK et al., 2011; FODOR et al., 2011; TOTTH et al., 2011; TOTTH et al., 2018a; TOTTH et al., 2018b) alapján megállapítható, hogy a fogyasztók vásárlói magatartása jelentősen eltér a különböző fogyasztási alkalmak esetében, ezért külön vizsgáltuk a saját fogyasztásra és ajándékozási céllal vásárolt pálinkák imázsát. A pálinkafogyasztás alapos megismerését nehezíti a kereskedelmi forgalomban kapható „bolti” pálinka, és a házi párlatok körül kialakult fogalmi zürzavar. Az Európai Parlament és a Tanács által jegyzett, 110/2008/EK rendelet (2008. ÉVI LXXIII. TÖRVÉNY, 2008) értelmében uniós oltalomban részesül a „Pálinka” és „Törkölypálinka” megjelölés, vagyis a pálinka elnevezés kizárólag Magyarországon (illetve barackpárlatok esetében további 4 osztrák tartományban) használható. A jogszabály értelmében a bérfo"ző által gyártott, illetve otthon fözött termékre nem alkalmazható a pálinka kifejezés, csak a párlat. Ezért a tanulmányban a házi párlat kifejezést használjuk a közbeszédben elterjedt és helytelenül használt „házi pálinka” helyett.

Az otthoni pálinkafőzés és bérfőzés törvényi szabályozásának az utóbbi tevekénységek számára igen kedvező alakulása a házi párlatok népszerüségének növekedését eredményezték. A kereskedelmi főzés visszaesése a bérfözdék termelésének a növekedésével párosult, a Pálinka Nemzeti Tanács (PÁLINKA NEMZETI TANÁCS, 2019) szerint az ágazat nem transzparens. Számos, a pálinkafogyasztással foglalkozó hazai kutatás (TOTTH, 2009; FODOR et al., 2011; SZEGEDYNÉ et al., 2017; TOTTH et al., 2017) rávilágított a pálinkával kapcsolatos fogalmi zavarokra, a pálinkával kapcsolatos fogyasztói attitűd kognitív komponense meglehetősen gyenge.

\subsection{Imázs - Image}

MÓRICZ (1991) értelmezésében az imázs egy tárgy, ember, cég vagy termékmárka érzelmi képzete, amit számos tényező befolyásol, és az emberben élő belső valóságnak tekinthető. A szakirodalom többféle csoportosítással különböző imázs típusokat határoz meg, úgymint gazdasági, társadalmi, politikai reálfolyamatok szerint létezik termék- (szolgáltatás), márkakép- (védjegy), vállalat-, személy illetve országimázs (TOTTH, 1996). A fogyasztói döntéshozatalban a márkaimázsnak fontos szerepe van. TOTTH (1996) megfogalmazásában a márkaimázs az a kép, amely a márkával azonosított termékről a hozzá kapcsolódó asszociációk alapján a vevőkben kialakul. A márka- 
imázs fontosságára hívja fel a figyelmet OLINS (2004) is, szerinte a márkaimázs akkor sikeres, ha a fogyasztó fejében egy adott termékcsoport vonatkozásában csak az adott márka létezik. HERRERO et al. (2016) szerint az imázs nagy hatást gyakorol a fogyasztói értékelésekre.

\subsection{Az imázs és az attitúd kapcsolata \\ - The Relationship Between Image and Attitude}

Az attitűd imázsformáló hatásának megértéséhez fontos az attitűd alaposabb vizsgálata. Az egyik legáltalánosabban elfogadott megfogalmazás ALLPORT (1935) nevéhez füződik, mely szerint az attitüd olyan idegi és mentális készenléti állapot, amely a fogyasztói tapasztalat révén jött létre. A fogyasztói attitűd, azaz a termékek, márkák felé irányuló pozitív, vagy negatív érzések erősen hatnak a tényleges vásárlói magatartásra (FISHBEIN és AJZEN, 1975; AUTHMAN, 1986). Az attitűd EAGLY és CHAIKEN (1993) megfogalmazásában nem más, mint egy adott termék kedvező, vagy kedvezőtlen megítélésével kapcsolatos pszichológiai tendencia.

Az attitưd és az imázs TOMCSÁNYI (1988) szerint kölcsönhatásban áll egymással, az imázs kép valamiről, az attitűd viszonyulás valamihez, és mindkettő befolyásolja a tényleges vásárlói magatartást. MALOTA (2003) meglátásában az imázst a személyes percepciók és benyomások alakítják, mellyel kapcsolatban a fogyasztónak személyes attitűdjei lehetnek. BRIJS et al. (2011) szerint az imázs a termék iránti attitűd előzményének tekinthető. $\mathrm{Az}$ imázs az attitűd és a sztereotípia között helyezkedik el. A fogyasztókban kialakult érzelmi imázs ELLIOT et al. (2011) megítélése szerint képes befolyásolni az attitűdöt.

\subsection{Az attitúd komponensei -}

The Attitude Components

A marketing szakirodalomban (HOFMEISTER-TÓTH, 2006; HAWKINS és MOTHERSBAUGH, 2012; HORVÁTH, 2012; SAS, 2012;
SCHIFFMAN és WISENBLIT, 2015) elterjedt legáltalánosabb nézet szerint az attitűdnek három komponense van.

A kognitív, vagy ismereti komponens az attitűd tárgyával kapcsolatos ismeretekre vonatkozik. A közvetlen tapasztalatokból, illetve különböző forrásokból származó információ kapcsán fontos kihangsúlyozni, hogy ez nem pusztán objektív ismeretet jelent. A fogyasztó ismerete lehet hiányos, téves, ezekben az esetekben pontosabb a hiedelem, vélemény, meggyőződés kifejezések használata. Az attitűd következő összetevője az affektív komponens, amely az attitűd tárgyával kapcsolatos érzéseket, érzelmeket jelenti, amely lehet pozitív vagy negatív irányú. A harmadik, ún. konatív komponens a kognitív és affektív hatásokra adott válasz, ami a vásárlási szándék, a tényleges fogyasztás megnyilvánulása. A fogyasztó természetes törekvése, hogy attitüdjének három komponense összhangban legyen egymással. A kognitív disszonancia, azaz a belső ellentmondások feloldása a komponensek egymáshoz hangolásával történik. A fent említett szakirodalmak alapján nagyon gyakori, hogy az attitűd affektív komponense befolyásolja az egész attitűdöt.

\subsection{Fogyasztói etnocentrizmus - Consumer Ethnocentrism}

A fogyasztói etnocentrizmust SUMNER (1960) fogalma alapján SHIMP és SHARMA (1987) definiálta, a fogalom a külföldi áruk beszerzését elutasító fogyasztói magatartást jelenti.

A szakirodalmi feldolgozás, valamint az égetett szeszes italok hazai fogyasztását feltáró kvalitatív kutatás (melynek eredményeit terjedelmi okok miatt jelen cikkben nem ismertetjük) segítségével fogalmaztuk meg hipotéziseinket. A házi párlat kedvező imázsának kialakulásában az affektív komponens szerepet játszik (H1). A házi párlat kedvező imázsának kialakulásában a konatív komponens szerepet játszik (H2). H3 hipotézisünk szerint a házi párlat kedvező imázsának kialakulásában szerepet játszik a fogyasztói etnocentrizmus. 


\section{ANYAg ÉS MÓDSZER - MATERIAL AND METHOD}

A kvantitatív vizsgálatot az égetett szeszes italok hazai fogyasztását feltáró kvalitatív kutatás (fókuszcsoportos megkérdezés, egyéni interjúk) előzte meg. A végleges kérdőív elkészítéséhez próbakérdezést végeztünk, melyet 205-en töltöttek ki, a végleges kérdőív kialakítása a próbakérdőív értékelése után pszichológus bevonásával történt. A kvantitatív kutatásra 2019 év vége-2020 év elején került sor, standard kérdőív alkalmazásával, kvótás mintavétel módszerével, személyes lekérdezéssel. A megkérdezettek olyan 18 év feletti felnőtt magyar lakosok voltak, akik a vizsgálatot megelőző három hónapban fogyasztottak pálinkát. A minta nem, korcsoport, és régió szempontjából megegyezik a 18 év feletti magyarországi lakosság összetételével (KSH, 2019a; KSH, 2019b). A minta demográfiai megoszlását, és a reprezentativitásra vonatkozó statisztikai próbákat az 1. számú táblázat tartalmazza. Az adatok elemzése SPSS 25.0 és Excel segítségével történt.

\section{TÁBLÁZAT}

TABLE 1

A minta szocio-demográfiai megoszlása (\%; fó)

(Demographic Data of Respondents (\%, capita))

\begin{tabular}{|c|c|c|c|}
\hline & & $\begin{array}{c}\text { KSH } 2019(\%) \\
(H C S O, 2019, \%)\end{array}$ & $\begin{array}{c}\text { Saját minta } \\
\text { (fö) (Sample, } \\
\text { capita) }\end{array}$ \\
\hline \multirow{2}{*}{ Nem (Gender) } & Férfi (Men) & 47,85 & 300 \\
\hline & Nő (Women) & 52,15 & 326 \\
\hline \multirow{6}{*}{ Korcsoport (Age group) } & 18-24 éves (18-24-year-old) & 9,42 & 67 \\
\hline & 25-34 éves (25-34-year-old) & 15,40 & 109 \\
\hline & 35-44 éves (35-44-year-old) & 19,08 & 117 \\
\hline & 45-54 éves (45-54-year-old) & 16,84 & 106 \\
\hline & 55-64 éves (55-64-year-old) & 15,82 & 99 \\
\hline & 65 év felett (older than 65 years) & 23,44 & 128 \\
\hline \multirow{8}{*}{ Régió (Region) } & Budapest (Budapest) & 17,93 & 114 \\
\hline & Pest (Pest) & 13,09 & 82 \\
\hline & Észak-Magyarország (North Hungary) & 11,53 & 72 \\
\hline & Észak-Alföld (North-Great Plain) & 14,85 & 93 \\
\hline & Dél-Alföld (South-Great Plain) & 12,66 & 79 \\
\hline & Közép-Dunántúl (Central Transdanubia) & 10,83 & 68 \\
\hline & Nyugat-Dunántúl (West-Transdanubia) & 10,12 & 61 \\
\hline & Dél-Dunántúl (South-Transdanubia) & 9,00 & 57 \\
\hline
\end{tabular}

Forrás (Source): Saját szerkesztés, 2020, N=626 (Authors'own compilation, 2020, $N=626$ )

Megjegyzés (Note): Reprezentativitás (Representativity): nem (gender) (observed prop. $=0,5208$; test prop. $=0,5215$; $\mathrm{p}=0,501)$; korcsoport (age group) $\left[\mathrm{\chi}^{2}(\mathrm{df}=5, \mathrm{~N}=626)=5,334, \mathrm{p}=0,376\right]$; régió (region) $\left[\mathrm{x}^{2}(\mathrm{df}=7, \mathrm{~N}=626)=0,115, \mathrm{p}=1,000\right]$

Az attitűd méréséhez szükséges az attitűd összetevőinek megismerése. ROSENBERG (1956, 1960) az attitüdöt két kognitív tényező függvényeként írta le. VAUGHN (1980) szerint a háromdimenziós attitűd komponensei egymás utáni hierarchiával rendelkezhetnek egy adott termék vonatkozásában. BACK és PARKS (2003) meghatározásában márka attitűdök esetében ez a sorrend a kognitív, affektív, ko- natív komponensek egymásutániságát jelenti. AJZEN 2005-ös megfogalmazásában az attitűd definíciójának a kognitív, affektív, konatív komponenseket is tartalmaznia kell. Ezek az alkotóelemek képezik az attitűd mentális elemét. 2006-ban AJZEN ezt még kiegészítette azzal, hogy az attitűd lélektani befolyásolást jelent. BRINK (2008) rámutat, hogy az attitűd komponensek, a hiedelmek, érzelmek és viselkedés 
sokszor ellentmondásosak, azonban az emberek összhangot teremthetnek köztük. BEERLI és MARTIN (2004) szerint a fogyasztók a kognitív és affektív elemeket keverik össze ahhoz, hogy egy adott termékről (szolgáltatásról, márkáról) képet alkossanak. Annak ellenére, hogy ezek egymástól elkülönülő fogalmak, mégis befolyásolják egymást.

A kognitív rész az egyén ismereteit, hiedelmeit jelenti, az affektív komponens pedig az érzelmi érintettséget (FABRIGAR et al., 2005). ZAJONC és MARKUS (1982) úgy találták, hogy bizonyos esetekben az emberek a kognitív komponenst kevésbé figyelembe véve inkább a viselkedéshez vezető érzelmekre, hatásokra összpontosítanak. A kognitív komponens az ismereteket, a tudatosságot, megértést, hiedelmeket, az affektív az érzéseket, értékelést jelenti, a konatív komponens pedig a viselkedésre, a szándékra, a magatartásra vonatkozik. Számos kutatás (KRECH és CRUTCHFIELD, 1948; BRECKLER, 1984; KIPPER, 1986; DETENBER et al., 1998) foglalkozik a háromdimenziós attitüd modellel.

Az imázs ábrázolásának egyik legelterjedtebb, leglátványosabb megoldása (SAS, 2012) az imázsprofil alkalmazása, melyben 7 fokozatú skálán a különböző állításokra adott válaszok átlagait összekötve kirajzolódik a termékek imázsa.

A fogyasztói etnocentrizmus mérésére SHIMP és SHARMA (1987) 17 elemű állítás-listáját alkalmaztuk. SHARMA (2015) megítélésében az általuk kidolgozott skála bizonyítottan képes megjósolni a vásárlási szándékokat és a tényleges vásárlási viselkedést a hazai és a külföldi termékek esetében a világ számos országában, különböző termékkategóriákban. Azok a termékek, mint pl. az élelmiszer, amelyek alapvetőek egy ország gazdasága számára, JAFFE és NEBENZAHL (2001) szerint erősebb etnocentrikus viselkedést generálnak.

\section{EREDMÉNYEK - RESULTS}

\subsection{Az affektív komponens mérése - Measuring of the Affective Component}

Az affektív komponens mérésével a fogyasztó kialakult érzéseit tudjuk feltérképezni egy termék valamely tulajdonságáról vagy akár egy egész márkáról. Az általunk tanulmányozott marketing szakirodalom (HOFMEISTER-TÓTH, 2006; HAWKINS és MOTHERSBAUGH, 2012; HORVÁTH, 2012; SAS, 2012; SCHIFFMAN és WISENBLIT, 2015) alapján a fogyasztókat arra kértük, hogy bizonyos állításokkal szemben fejezzék ki egyetértésük mértékét a „nagyon egyetértek - egyáltalán nem értek egyet” skálán. Kérdőívünkben az attitűd komponensek részletes megismeréséhez a házi párlat, illetve bolti pálinka mellé a whiskyt választottuk összehasonlításul. A whisky az AC Nielsen piackutató (VILÁGGAZDASÁG, 2017) vizsgálata szerint népszerü égetett szeszes ital Magyarországon. Jelen tanulmány az affektív, konatív komponensekre koncentrál, azonban a kutatás kognitív attitűd komponensre irányuló vizsgálatában megfigyeltük a hazai fogyasztók whiskyről alkotott kedvező imázsát. A kérdőívben az affektív komponens számszerüsítésére 12 kérdést fogalmaztunk meg. Fontos kihangsúlyozni, hogy bizonyos kérdések kognitív, illetve affektív viszonylatban is értelmezhetőek. A Hungarikum fogalom értelmezése elsősorban ismereti kérdés, azonban szakmai indokkal végül az affektív kérdéscsoportba soroltuk. A kérdéscsoport belső konzisztenciáját vizsgáló Cronbach-alfa (CRONBACH, 1951) értékek meghaladták a 0,7-es határt [házi párlat $(0,845)$; bolti pálinka $(0,860)$; whisky $(0,820)$, amely szerint a kérdések megbízhatóan mérnek. Az 1. ábrán szemléltetjük a három égetett szeszes ital affektív imázsprofiljait. 
Kedvelem az ízét (I like the taste of it)

Kedvelem az illatát (I like the smell of it)

Hazafias dolognak tartom a fogyasztását (It is patriotic to consume)

Fogyasztása jókedvre derít (Consumption of it is fun)

Megbízható, állandó jó minôségủ ital (Reliable, high quality drink)

A házi készítésủ megbízhatóbb minőségü, mint a bolti (Homemade is more reliable)

Fogyasztásától nem hízom el (Do not gain weight)

Nem lehet rászokni (Not addictive)

Fogyasztása férfias (It is masculine to consume)

Hungarikum (Hungarikum)

Fogyasztása divatos (It is trendy to consume)

Fogyasztása magas státuszt jelent (It is poshy to consume)

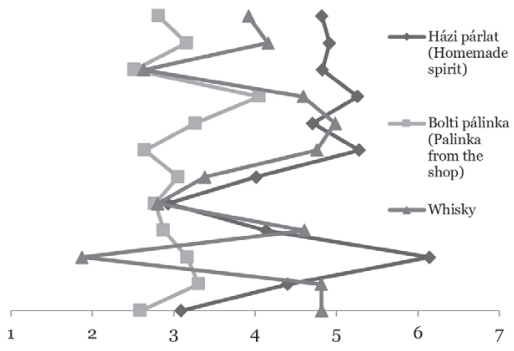

1. ÁBRA

FIG. 1

Házi párlat, bolti pálinka, whisky imázsprofilja (1=egyáltalán nem ért egyet, $7=$ =nagyon egyetért) (Imageprofil of the Whiskey, Homemade Spirit and Pálinka from the Shop (1=strongly disagree, $7=$ strongly agree))

Forrás (Source): Saját szerkesztés, 2020, N=626 (Authors' own compilation, 2020, $N=626$ )

Az attitüd affektív komponensére irányuló vizsgálat szerint a megkérdezettek érzelmileg legjobban a házi párlathoz kötődnek, második a whisky, a kereskedelmi forgalomban kapható „bolti” pálinka pedig az utolsó helyet szerezte meg. A válaszadók a három ital közül leginkább a házi párlat ízét és illatát szeretik a legjobban, melyet a whisky, majd a bolti pálinka követ. A hazafiasságot firtató állítás tekintetében a mintában résztvevők a bolti pálinka és a whisky fogyasztását egyformán kevésbé hazafiasnak gondolták (7-es skálán 2,5-ös átlaggal). A megkérdezettek szerint a házi párlat fogyasztása ellenben hazafias cselekedet. Az ötödik állításra („megbízható, állandó minőségű ital”) kapott válaszok alapján a whisky és a házi párlat fej-fej mellett halad, a bolti pálinka pedig messze lemarad tőlük. A hatodik állítás („,a házi készítésű megbízhatóbb, mint a bolti”) vonatkozásában tisztában voltunk azzal, hogy a házi készítésű whisky fogyasztása nem jellemző hazánkban, azonban ez a kérdés a házi párlat/bolti pálinka közötti különbség burkolt érzékeltetésére irányult. A válaszadók a házi párlatokat egyértelműen megbízhatóbb minőségűnek tartják, mint a bolti pálinkát, ami nem csak érzelmi, hanem ismereti probléma is. Ismereti és affektív probléma továbbá a Hungarikum kérdése. A megkérdezettek a bolti pálinkát nem tartják Hungarikumnak, ellentétben a házi párlattal. A három ital összevetésében egyértelmüen a whisky fogyasztása számít státuszszimbólumnak.
H1 hipotézisünkben azt feltételeztük, hogy a házi párlat kedvező imázsának kialakulásában az affektív komponens szerepet játszik. Feltételezésünket kutatási eredményeink alátámasztották.

A pálinkafogyasztás még alaposabb megismeréséhez a demográfiai háttérváltozók tekintetében további imázsprofilokat készítettünk, amelyeket terjedelmi okokból nem tudunk megjeleníteni. A továbbiakban a legfontosabb eredményeket emeljük ki. Nemek tekintetében a férfiak érzelmileg jobban kötődnek a whiskyhez, mint a nők. A bolti pálinka mindkét nem esetében nagyon gyengén szerepelt, a férfiak még a whisky fogyasztását is hazafiasabb tevékenységnek gondolják, mint a kereskedelmi pálinkáét. Enyhe gyógyír a bolti pálinka gyártóinak, hogy a nők nem érzik olyan nagynak a távolságot a házi párlat és a bolti pálinka között megbízhatóság és minőség szempontjából, valamint a Hungarikum tekintetében is kicsit jobb a helyzet a nők esetében.

Korcsoport tekintetében a fiatalok körében is a házi párlathoz kapcsolódó érzelmek dominálnak, viszont nagyon népszerü a whisky, a minőség és megbízhatóság tekintetében megelőzi a pálinkákat. Ez a tendencia az idősebb korosztályokban, az 55 év felettieknél megfordul, náluk a három ital közül a legmegbízhatóbb minőségűnek a házi párlat számít. A bolti pálinka gyártók reményei az imázsprofilok alapján a 35-55 éves korosztályban lehetnek, náluk az értékek kevésbé voltak a kereskedelmi pálinkákra nézve elmarasztalóak. 


\subsection{A konatív komponens mérése -} Measuring of the Conative Component

A marketing szakirodalmak (HOFMEISTER-TÓTH, 2006; HAWKINS és MOTHERSBAUGH, 2012; HORVÁTH, 2012; SAS, 2012; SCHIFFMAN és WISENBLIT, 2015) szerint a konatív komponens vizsgálatával azt próbáljuk kideríteni, hogy mi a tényleges vásárlás bekövetkezésének a valószínúsége. Ezért az erre az összetevőre irányuló kérdések a jelenlegi vásárlási szokásokra és a jövőbeni vásárlási szándékra vonatkoznak. FISHBEIN és AJZEN (1980) szerint azonban az eredmények értékelésénél érdemes figyelembe venni, hogy a fogyasztók nem cselekszenek mindig következetesen, elözetes szándékaikkal összhangban. A kérdőívben a konatív komponens számszerüsítésére 6 kérdést fogalmaztunk meg. A kérdéscsoport belső konzisztenciáját vizsgáló Cronbach-alfa (CRONBACH, 1951) értékek meghaladták a o,7-es határt [házi párlat (0,908); bolti pálinka $(0,906)$; whisky $(0,923)]$, amely szerint a kérdések megbízhatóan mérnek.

A 2. ábrán pókháló diagram segítségével szemléltetjük a három égetett szeszes ital konatív imázsprofiljait.

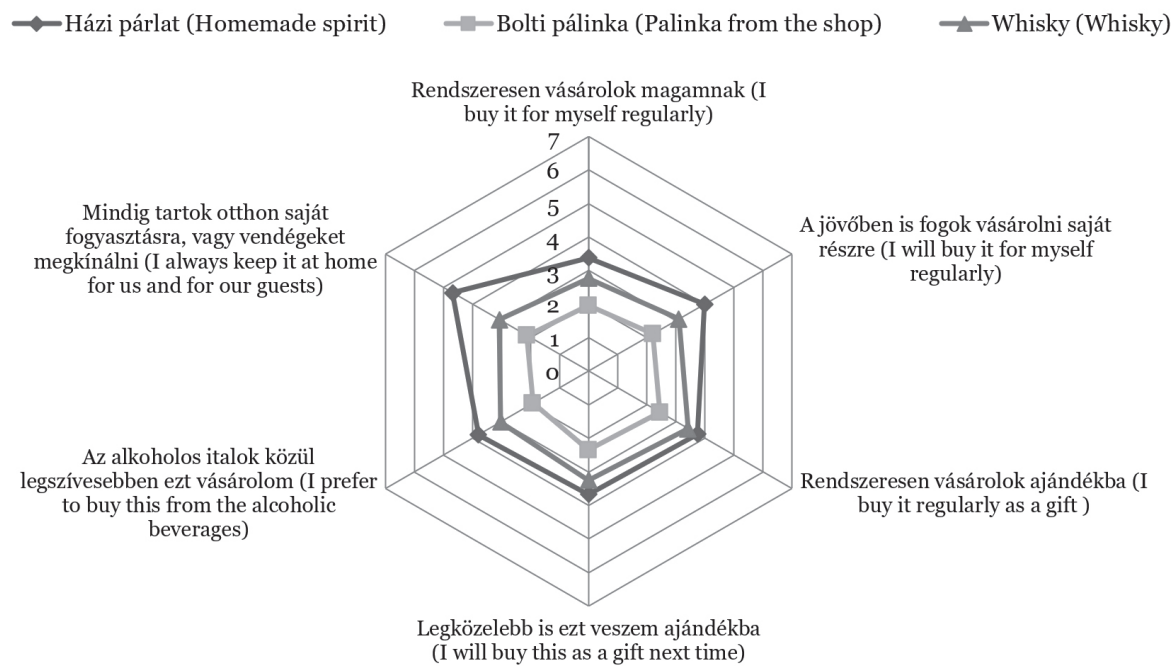

2. ÁBRA

FIG. 2

Házi párlat, bolti pálinka, whisky imázsprofilja a magatartási komponens vonatkozásában (1=egyáltalán nem ért egyet, $7=$ nagyon egyetért)

(Imageprofil of the Conative Component of Whiskey, Homemade Spirit and Pálinka from the shop (1=strongly disagree, $7=$ strongly agree))

Forrás (Source): Saját szerkesztés, 2020, N=626 (Authors' own compilation, 2020, N=626)

Az affektív komponens vizsgálatakor megfigyelt sorrend a magatartási blokk eredményében is megjelent. A válaszadók minden vonatkozásban a házi párlatot preferálják, amit a whisky követ, a sort pedig a bolti pálinka zárja. A termékek otthoni készletét vizsgálva még szembetűnőbb a különbség a házi párlat javára. A sorrend mind a jelenlegi saját célra és aján- dékba történő vásárlás, mind pedig a jövőbeni szándékra vonatkozóan is ugyanaz maradt.

A konatív komponens még alaposabb megismeréséhez a demográfiai háttérváltozók tekintetében további imázsprofilokat készítettünk, a legszembetűnőbb grafikont a 3. ábrán mutatjuk meg. 


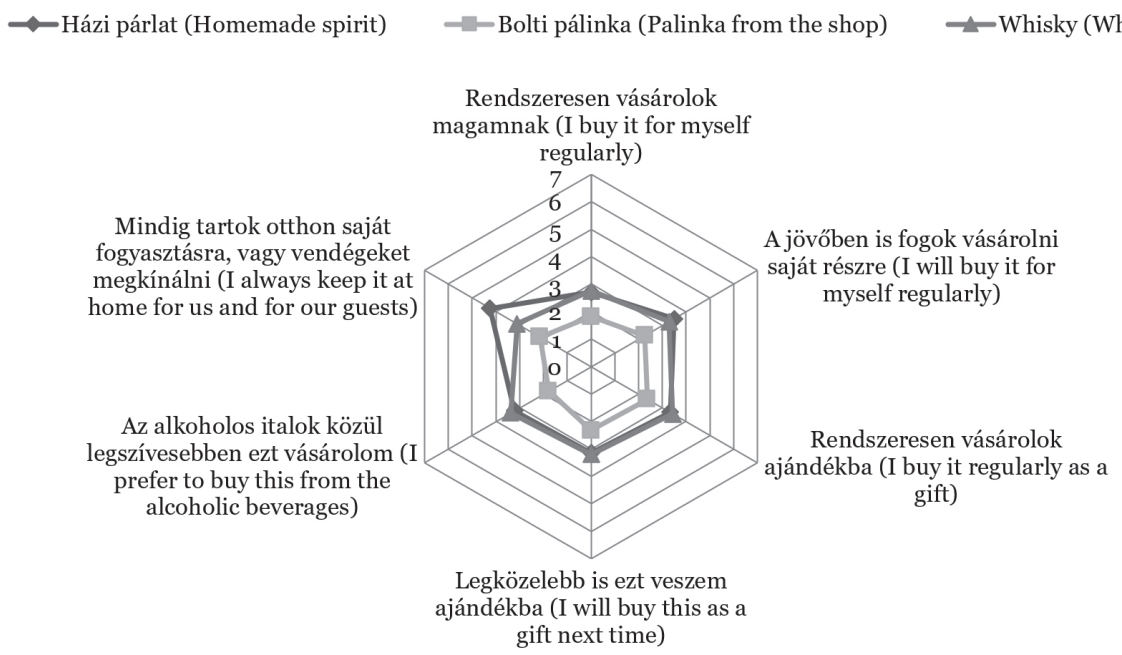

FIG. 3

3. ÁBRA gift next time)

Házi párlat, bolti pálinka, whisky imázsprofilja a magatartási komponens vonatkozásában a 25-34 éves korosztályban (1=egyáltalán nem ért egyet, $7=$ =nagyon egyetért)

(Imageprofil of the Conative Component of Whiskey, Homemade Spirit and Pálinka from the Shop in the 25-34 Agegroup (1=strongly disagree, $7=$ strongly agree))

Forrás (Source): Saját szerkesztés, 2020, N=626 (Authors' own compilation, 202O, N=626)

A 25-34 éves korosztály magatartási szokásait vizsgálva szembetűnő, hogy a whisky eléri a házi párlat szintjét majdnem az összes vonatkozásban. A házi párlat otthoni fogyasztásra, vagy vendégeket várni a megkérdezettek szerint a három ital közül a legjobb választás. A kereskedelmi pálinka gyártóinak rossz hír, hogy a konatív komponenst vizsgálva a bolti pálinkák messze lemaradtak a másik két italtól.

H2 hipotézisünk szerint a házi párlat kedvező imázsának kialakulásában a konatív komponens szerepet játszik. Hipotézisünket kutatási eredményeink megerősítették.

\subsection{A fogyasztói etnocentrizmus és pálinka imázs kapcsolata - The Relationship Between Consumer Ethnocentrism and the Image of Pálinka}

\subsubsection{A fogyasztói etnocentrizmus és az affektív komponens kapcsolata - The Relationship Between Consumer Ethnocentrism and the Affective Component}

Válaszadóinkat az etnocentrikus fogyasztói magatartást vizsgáló 17 elemű állításlistára adott válaszaik alapján egyenlő elemszámú csoportokból kiindulva három csoportra osztottuk (kevésbé etnocentrikus, közepesen etnocentrikus, etnocentrikus). Az affektív és konatív komponensekre adott válaszok alapján is ugyanígy jártunk el. A fogyasztói etnocentrizmus és az affektív attitűd komponens közötti kapcsolatot vizsgálva szignifikáns összefüggést kaptunk ( $\chi^{2}=81659 ; \mathrm{df}=4 ; \mathrm{p}<0,001, \gamma=0,455$; $\mathrm{p}<0,001)$ a házi párlat esetében. Az ordinális skálák közötti kapcsolat a Gamma értéke alapján közepes erősségü. A kevésbé etnocentrikus válaszadók $54,1 \%$-a a házi párlatra vonatkozó érzelmi töltetű állításokra a legkevesebb pontot adók közül került ki. Mindössze 20,6\%-uk tartozott a házi párlatot érzelmileg kedvelő csoportba. Az etnocentrikus válaszadók 17,2\%a tartozott a házi párlathoz érzelmileg nem kötődők közé, 27,3\%-uk semleges, 55,5\%-uk pedig az affektív komponensre irányuló kérdésekre a legmagasabb válaszokat adta. Az ebbe a csoportba tartozó válaszadók 18,9\%-a kevésbé etnocentrikus, 30,3\%-a közepesen etnocentrikus, 50,9\%-a pedig etnocentrikus fogyasztó.

A fogyasztói etnocentrizmus és az affektív attitűd komponens közötti kapcsolatot vizsgálva a bolti pálinka esetében a következő ered- 
ményeket kaptuk: $\chi^{2}=13818 ; \mathrm{df}=4 ; \mathrm{p}=0,008$, $\gamma=0,076 ; p=0,144$. Habár a khí négyzet teszt még szignifikáns, azonban a Gamma már nem az, és az értéke is elhanyagolható. A bolti pálinka esetében az etnocentrikus válaszadók 35,4\%-a tartozott a bolti pálinkához érzelmileg nem kötődők közé, 33,0\%-uk semleges, 31,6\%uk pedig az affektív komponensre irányuló kérdésekre a legmagasabb válaszokat adta. A bolti pálinkához érzelmileg leginkább kötődő válaszadók 24,9\%-a kevésbé etnocentrikus, 42,3\%-a közepesen etnocentrikus, 32,8\%-a pedig etnocentrikus fogyasztó.

A fogyasztói etnocentrizmus és az affektív attitűd komponens közötti kapcsolatot vizsgálva a whisky esetében nem találtunk szignifikáns összefüggést.

\subsubsection{A fogyasztói etnocentrizmus és a konatív komponens kapcsolata - The Relationship Between Consumer Ethnocentrism and the Conative Component}

A fogyasztói etnocentrizmus és a konatív attitűd komponens közötti kapcsolatot vizsgálva szignifikáns összefüggést találtunk ( $\chi^{2}=66942$; $\mathrm{df}=4 ; \mathrm{p}<0,001, \gamma=0,403 ; \mathrm{p}<0,001)$ a házi párlat esetében. Az eredmények majdnem teljesen megegyeznek az affektív komponensnél mért adatokkal. Az etnocentrikus válaszadók 23,4\%a tartozott a házi párlathoz magatartás szempontjából nem kötődők közé, 23\%-uk semleges, 53,6\%-uk pedig szívesen tartja és vásárolja a házi párlatot. Az ebbe a csoportba tartozó válaszadók 18,6\%-a kevésbé etnocentrikus, 30,8\%-a közepesen etnocentrikus, 50,7\%-a pedig etnocentrikus fogyasztó.

A fogyasztói etnocentrizmus és a konatív attitűd komponens közötti kapcsolatot vizsgálva a bolti pálinka esetében szintén az affektív részhez hasonló értékeket kaptunk $\left(\chi^{2}=16394\right.$; $\mathrm{df}=4 ; \mathrm{p}=0,003, \mathrm{\gamma}=0,035 ; \mathrm{p}=0,503)$.

Szignifikáns kapcsolatot tártunk fel a fogyasztói etnocentrizmus és a konatív attitűd komponens közötti kapcsolatot vizsgálva a whisky esetében $\left(\chi^{2}=14560 ; d f=4 ; p=0,006\right.$, $\gamma=-0,144 ; p=0,007)$. A Gamma negatív értéke mutatja az ellentétes irányú összefüggést, az etnocentrikus fogyasztók 43,1\%-a csak ritkán vásárol, és tart whiskyt, 35,4\%-uk néha, és mind- össze 21,5\%-uk adott a konatív komponensre irányuló kérdésekre magas pontszámú választ.

H3 hipotézisünk szerint a házi párlat kedvező imázsának kialakulásában szerepet játszik a fogyasztói etnocentrizmus. Hipotézisünket kutatási eredményeink megerősítették.

\section{KÖVETKEZTETÉSEK ÉS JAVASLATOK - CONCLUSIONS AND PROPOSALS}

A marketing szakirodalmak (HOFMEISTER-TÓTH, 2006; HAWKINS és MOTHERSBAUGH, 2012; HORVÁTH, 2012; SAS, 2012; SCHIFFMAN és WISENBLIT, 2015) szerint az attitúd megváltoztatásához gyakran elegendő az egyik komponenst megváltoztatni. Az affektív komponens befolyásolására jól alkalmazható a klasszikus kondicionálás. Ebben a módszerben olyan ingert alkalmaznak, amelyet a fogyasztók kedvelnek, majd ezt következetesen az adott termékkel, márkával párosítják. A megfelelő kondicionálás után ez a kellemes hatás egybeforr a termékkel, márkával. Az affektív komponens befolyásolása fontos marketing feladat, és a reklámpszichológia területe. Számos reklámban a terméket valamilyen pozitív érzelmi tartalommal kapcsolják össze. Szintén az affektív komponens megváltoztatását célozza a szponzorálás, amelynek célja, hogy a célközönség által kedvelt esemény iránt érzett pozitív attitűd a márkára is kiterjedjen. A magatartási komponens befolyásolása, illetve módosítása történhet az operáns kondicionáláson keresztül. SMITH és SWINYARD már 1983-ban kimutatta, hogy egy termék kipróbálása sokkal inkább vezetett attitűdváltozáshoz, mint önmagukban csak a reklámok. Mivel az alkoholtartalmú italok reklámozása hazánkban csak rendkívül szigorú megszorításokkal lehetséges (REKLÁMTÖRVÉNY, 2008. 18. §), az egyik legfontosabb marketingfeladat lehet a termék megvásárlásának elősegítése, de egyben arról is fontos gondoskodni, hogy a termék megvásárlása, fogyasztása, illetve használata elégedettséghez vezessen. A hazai fogyasztók pálinkával kapcsolatos érzelmeinek, magatartásának a kedvező irányba történő elmozdítása a pálinka gyártók elemi érdeke. 


\section{6. ÖSSZEFOGLALÁS - SUMMARY}

A kutatás célja a hazai pálinkafogyasztás, valamint a pálinkához kapcsolódó imázs újszerü megközelítése volt. A fogyasztói attitűd komponensek imázs kialakító szerepét vizsgáltuk a bolti pálinkára, valamint a házi párlatra koncentrálva, az összehasonlításba egy népszerü külföldi italt, a whiskyt bevonva. A szakirodalom tanulmányozását követően kvalitatív vizsgálatot végeztünk, amely feltárta a kvantitatív kutatás legfontosabb szempontjait. A kvantitatív vizsgálat standard kérdőívezéssel, kvótás mintavétel módszerével történt, a minta 626 érvényes kitöltővel három szempontra (nem, korcsoport, régió) nézve megfelelő arányban képviseli a 18 éven felüli hazai lakosságot.

Az attitűdvizsgálatban skálás kérdőív segítségével tettük számszerűsíthetővé a fogyasztói érzések és magatartás rejtett összefüggéseit. A fogyasztói attitűd affektív és konatív komponensét vizsgálva megállapítottuk, hogy a házi párlathoz köthető érzelmi és magatartásbeli formációk messze megelőzik a bolti pálinka megítélését. A bolti pálinkának a házi párlatokhoz képesti rossz imázsa mögött nemcsak ismereti, tudásbeli hiányosságok és tévedések húzódnak meg, hanem érzelmi és magatartásbeli okok is. A bolti pálinka imázsának a javítása a kereskedelmi pálinka gyártóinak elemi érdeke, ez a feladat azonban átfogó, mindhárom attitűd komponensre kiterjedő marketing stratégiát igényel. Csak így őrizhetik meg versenyképességüket.

\section{IRODALOMJEGYZÉK - REFERENCES}

2008. évi LXXIII. törvény: A pálinkáról, a törkölypálinkáról és a Pálinka Nemzeti Tanácsról. 2008. URL: https://net. jogtar.hu/jogszabaly?docid=ao800073.tv (Letöltés dátuma: 2019.10.10.)

Ajzen, I.: Attitude, Personality and Behavior. Open University Press, New York, 2005.

Ajzen, I.: Constructing a TPB Questionnaire: Conceptual and Methodological Consideration, 2006. URL: https://people. umass.edu/aizen/tpb.html

(Letöltés dátuma: 2020.02.10.)
Allport, G.: Attitudes. Halász, L. - Hunyadi Gy. - Marton, L.: Az attitűd pszichológiai kutatásának kérdései, Akadémiai Kiadó, 1935 .

Authman, Y. R.: Approche marketing du comportement de consommateur, Test de different models appliqués aux produits electro-managers, these doctorate d'etates-sciences de gestion. Universite Clermont I, France, 1986. 37-42.

Back, K. J. - Parks, S.: A Brand Loyalty Model Involving Cognitive, Affective, and Conative Brand Loyalty and Customer Satisfaction. Journal of Hospitality \& Tourism Research. 2003. 27 419-435. DOI: https://doi. org/10.1177/10963480030274003

Balázs, G.: Nagy párlat- és pálinkakönyv, Budapest: Inter Kft., 2012.

Beerli, A. - Martín, J. D.: Factors Influencing Destination Image. Annals of Tourism Research. 2004. 31 657681. DOI: https://doi.org/10.1016/j. annals.2004.01.010

Breckler, S. J.: Empirical Validation of Affect, Behavior, and Cognition as Distinct Components of Attitude. Journal of Personality and Social Psychology. 1984. 47 1191-1205. DOI: https://doi. org/10.1037/0022-3514.47.6.1191

Brijs, K. - Bloemer, J. - Kasper, H.: Country-Image Discourse Model: Unraveling Meaning, Structure, and Function of Country Images. Journal of Business Research. 2011. 64 12591269. DOI: https://doi.org/10.1016/j. jbusres.2011.01.017

Brink, T. L.: Psychology a Student Friendly Approach. Social Psychology. 2008. 13 295.

Cronbach, L. J.: Coefficient Alpha and the Internal Structure of Tests. Psychometrika. 1951. 16 (3) 297-334. DOI: https://doi. org/10.1007/bfo2310555

Detenber, B. H. - Simons, R. F. Bennett, G. G.: Roll 'em!: The Effects of Picture Motion on Emotional Responses. Journal of Broadcasting \& Electronic Media. 1998. 42 113-127. DOI: https:// doi.org/10.1080/08838159809364437 
Eagly, A. - Chaiken, S.: The Psychology of Attitudes; Harcourt Brace Jovanovich: Fort Worth, TX, USA, 1993.

Elliot, S. - Papadopoulos, N. - Kim, S. S.: An Integrative Model of Place Image: Exploring Relationships Between Destination, Product, and Country Images. Journal of Travel Research. 2011. 50 520-534. DOI: https://doi. org/10.1177/0047287510379161

Fabrigar, L. - MacDonald, T. - Wegener, D.: The Structure of Attitudes. In: Handbook of Attitudes. Albarracin, D. - Johnson, B. T. - Zanna, M. P. (Eds.) Lawrence Erlbaum Associates: Mahwah, NJ, USA, 2005. 79-124.

Fishbein, M. - Ajzen, I.: Beliefs, Attitude, Intention, and Behavior, an Introduction to Theory and Research. Reading MA: Addison-Wesley. 1975.

Fishbein, M. - Ajzen, I.: Predicting and Understanding Consumer Behavior: Attitude-Behavior Correspondence. Understanding Attitudes and Predicting Social Behavior. 1980. 148-172.

Fodor, M. - Hlédik, E. - Totth, G.: Fogyasztói vélemények és preferenciák a pálinka piacán. Élelmiszer, Táplálkozás és Marketing. 2011. 8 (1-2) 41-47.

Harcsa, I. M. - Nábrádi, A. - Tar, I.: Hungarian Spirits Pálinka as a "Hungaricum" I., ABSTRACT - Applied Studies in Agribusiness and Commerce, 2014. 8 (2-3) 133-141. DOI: https://doi. org/10.19041/apstract/2014/2-3/16

Hawkins, D. I. - Mothersbaugh, D. L.: Consumer Behaviour, McGraw-Hill Education, 2012. 416-418.

Herrero, A. - San Martín, H. - de los Salmones, M. - Collado, J.: Examining the Hierarchy of Destination Brands and the Chain of Effects Between Brand Equity and Dimensions. Journal of Destination Marketing \& Management. 2016. DOI: https://doi.org/10.1016/j. jdmm.2016.05.001

Hlédik, E. - Totth, G. - Fodor, M.: A pálinkavásárlási döntést befolyásoló tényezők. Marketing és Menedzsment. 2011. 45 (2) 16-22.
Hofmeister-Tóth, Á.: Fogyasztói magatartás, Aula Kiadó, 2006. p. 246.

Horváth, Á.: Az attitűd és az imázs. In: Horváth Á. (szerk.): Fogyasztói magatartás. Perfekt Kiadó. Budapest. 2012. 100-108.

Jaffe, E. D. - Nebenzahl, I. D.: National Image and Competitive Advantage: The Theory and Practice of Country-of-Origin Effect. Copenhagen Business School Press, Copenhagen, 2001.

Kipper, P.: Television Camera Movement as a Source of Perceptual Information. Journal of Broadcasting \& Electronic Media. 30. 1986. 295-307. DOI: https:// doi.org/10.1080/08838158609386625

Krech, D. - Crutchfield, R. S.: Theory of Probability for Social Psychology. McGraw-Hill: New York, NY, USA, 1948.

KSH: A lakónépesség korcsoport szerint, január 1. (2001-). 2019a. URL: https:// www.ksh.hu/docs/hun/xstadat/xstadat_ eves/i_wdsdoo4c.html (Letöltés dátuma: 2019.10.10.)

KSH: A lakónépesség nem szerint, január 1. (2001-). 2019b. URL: https://www. ksh.hu/docs/hun/xstadat/xstadat_ eves/i_wdsdoo3c.html (Letöltés dátuma: 2019.10.10.)

Malota, E.: Fogyasztói etnocentrizmus. A sztereotípiák, az etnocentrizmus és az országeredet imázs hatása a hazai és a külföldi termékek megítélésére (Doctoral dissertation, Budapesti Corvinus Egyetem). 2003.

Móricz, É.: Reklámpszichológia, Budapest, BKÁE Marketing Tanszék, 1991.

Olins, W.: A Má@kák, Budapest Jószöveg Műhely, 2004.

Pálinka Nemzeti Tanács: Ki fogja végezni a kormány a pálinkafózést. 2019. URL: https://www.palinkanemzetitanacs.hu/ hu/aktualitasok/42 (Letöltés dátuma: 2020.02.12.)

Reklámtörvény: 2008. évi XLVIII. törvény a gazdasági reklámtevékenység alapvető feltételeiről és egyes korlátairól, 18. §. URL: https://net.jogtar.hu/ jogszabaly?docid=ao800048.tv (Letöltés dátuma: 2020.07.20.) 
Rosenberg, M. J.: Cognitive Structure and Attitudinal Affect. The Journal of Abnormal and Social Psychology. 1956. 53 367-372.

Rosenberg, M. J.: An Analysis of AffectiveCognitive Consistency. In: Rosenberg, M. J. Hovland, C. I. - McGuire, W. J. Abelson, R. P. J. W. Brehm (Eds.), Attitude organization and change. Yale University Press, 1960.

Sas, I.: Reklám és pszichológia a webkorszakban - Upgrade 3.0, Kommunikációs Akadémia Kft. 2012. p. 217.; 223-260.

Schiffman, L. G. - Wisenblit, J.: Consumer Behavior. 11 th Global Edition. Pearson. Boston. 2015.

Sharma, P.: Consumer Ethnocentrism: Reconceptualization and Cross-Cultural Validation. Journal of International Business Studies. 2015. 46 381-389. DOI: https://doi.org/10.1057/jibs.2014.42

Shimp, T. A. - Sharma, S.: Consumer Ethnocentrism: Construction and Validation of the CETSCALE. Journal of Marketing Research. 1987. 24 (3) 280-289 DOI: https://doi.org/10.2307/3151638

Smith, R. E. - Swinyard, W. R.: AttitudeBehavior Consistency: The Impact of Product Trial Versus Advertising. Journal of Marketing Research. 1983. 20 (3) 257-267. DOI: https://doi. org/10.2307/3151829

Sumner, W. G.: Folkways: A Study of the Sociological Importance of Usages, Manners, Customs, Mores, and Morals. Boston, Ginn and Company. 1960. DOI: https://doi. org/10.1177/009182966000700209

Szegedyné, F. Á. - Szakos, D. - Bódi, B. Kasza, Gy.: Pálinka, fogyasztói ismeretek, preferenciák, fogyasztói szokások, marketinglehetőségek. Gazdálkodás. 2017. 60 (2) 158-170.

Tomesányi, P.: Az élelmiszer-gazdasági marketing alapjai. Mezőgazdasági Kiadó Bp. 1988.
Totth, G. - Hlédik, E. - Fodor, M.: Pálinkával kapcsolatos fogyasztói percepciók és preferenciák elemzése kvalitatív kutatás eredményeinek tükrében. Marketing és Menedzsment. 2011. 45 (2) 11-15.

Totth, G. - Mezőné Oravecz, T. - Zarándné Vámosi, K.: A pálinkafogyasztás és a fogyasztói szokások változása. Prosperitas. 2018a. 2018/2. 87-98. http://dx.doi.org/10.31570/ Prosp_2018_02_5

Totth, G. - Mezőné Oravecz, T. Zarándné Vámosi, K.: A pálinka fogyasztási és vásárlási szokásainak kvalitatív vizsgálata. Prosperitas. 2018b. 2018/2. 99-115. http://dx.doi. org/10.31570/Prosp_2018_02_6

Totth, G.: A vállalati imázs kialakításának és fenntartásának módszertana, Budapest BKE Vezetőképző Intézet, 1996.

Totth, G.: Stratégiai kihívások a megváltozott gazdasági környezetben a minőségi pálinka hazai forgalmazásában. in Losoncz, M., Solt K., Szigeti C. (szerk.): Kautz Gyula emlékkötet: Halálának 100. és születésének 180. évfordulója alkalmából. Győr: Széchenyi István Egyetem, 2009. 233-242.

Totth, G. - Kovács, I. - Mezőné, O. T. - Zarándné, V. K.: A fiatalok pálinkafogyasztási szokásai. In: Bányai, E. - Lányi, B. - Törőcsik, M. (szerk.): Tükröződés, társtudományok, trendek, fogyasztás: Egyesület a Marketing Oktatásért és kutatásért (EMOK) XXIII. országos konferencia: Tanulmánykötet, 2017. 230-238.

Vaughn, R.: How Advertising Works: A Planning Model. Journal of Advanced Research. 1980. 20 27-33.

Világgazdaság: Töménybe ölt tízmilliárdok. 2017. URL: https://www.vg.hu/gazdasag/ tomenybe-olt-tizmilliardok-2-670247/ (Letöltés dátuma: 2019.10.20.)

Zajonc, R. B. - Markus, H.: Affective and Cognitive Factors in Preferences. Journal of Consumer Research. 1982. 9 123-131. DOI: https://doi.org/10.1086/208905 